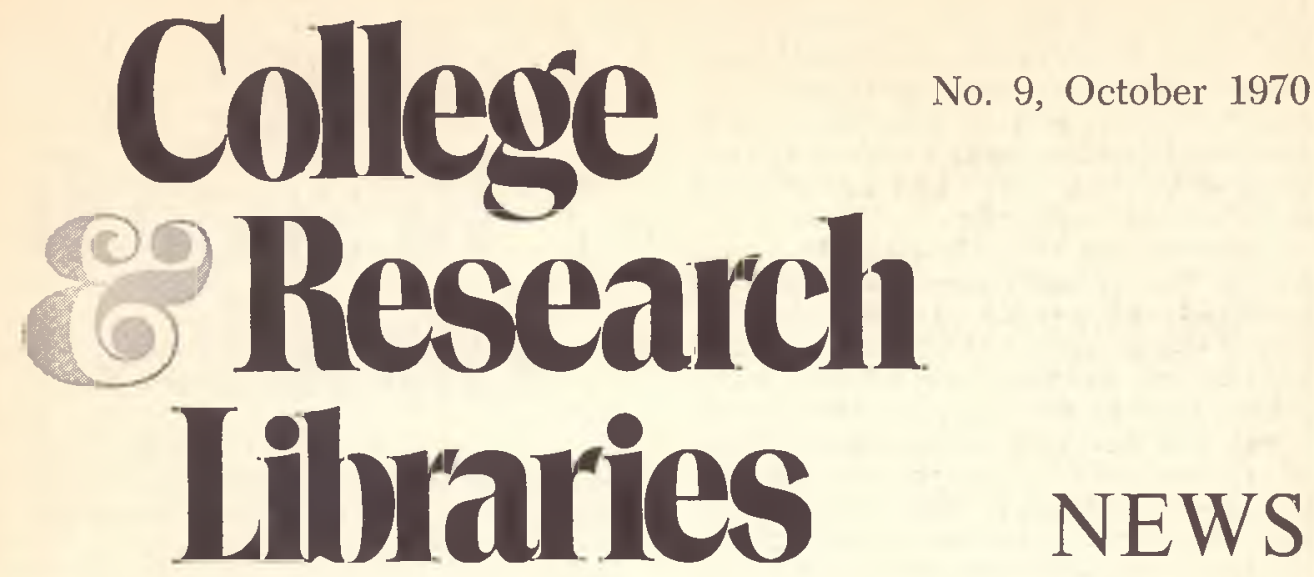

ACRL News Issue (B) of College \& Research Libraries, Vol. 31, No. 5

\title{
ACRL Academic Status Committee Proposes Standards for Librarians
}

ACRL's new, permanent Academic Status Committee has had a short but rocky career. Committee members, noted below, are widely scattered geographically and one of the committee's problems has been to find time and places to meet often enough to get the job done. Life was further complicated by the desire of CRL's membership to participate in closed working sessions of the committee at the recent ALA convention.

The Committee benefited from the work of the previous ad hoc committee, chaired by Lewis Branscomb of Ohio State University. Several of its present members worked up good position papers which were also helpful.

It became apparent early that our major chore was to define academic or faculty status and to propose specific standards upon which we could get agreement and, ultimately, the support of the ACRL and ALA. This was complicated by numerous requests for help from threatened librarians in many colleges and universities, requests we could and can do little or nothing about at this time.

Assaults on the academic nature and status of librarianship at institutions in California, New Jersey, New York, Pennsylvania, Missouri, and other states gave a sense of urgency to the committee's work. Many of us felt that in the great ALA tradition of too little and too late, we could, in effect, only lament the destruction of gains already painfully made around the country and deplore the lack of substantive ACRL support. At a time when academic administrators are suddenly faced with tighter budgets, when a crisis in public confidence in higher education has burgeoned, and when a buyer's personnel market has developed rather suddenly, the legitimate claims of librarians for an elevated position in the academic community, for more money, for participation in decision making, for tenure, senate membership, sabbatic leaves, etc., can be brushed aside more easily now than they could have been five or ten years ago. Faculties, too, are concerned about their own perks and privileges and are less likely to welcome librarians whom they often see as a threat to their own unique position.

These things being so, in order to prevent a further eroding of the librarians' status, we feel that ACRL must have at headquarters a staff which can devote full time to an educational mission to university administrators and accrediting bodies, to investigating various cases that come up, and to making on-site visits when necessary. Such a staff must not only have agreed-upon standards, but the strength and prestige of ACRL and ALA behind it. We feel that the ALA must adopt standards and be willing to use both persuasion and sanctions against those institutions which do not or will not grant full academic status to its librarians. In the thinking of most Committee 
members, this is the single most important issue facing ACRL at this time. Many of our concerns-freedom to read, intellectual freedom, the involvement of librarians in social issues-will be much more amenable to resolution if librarians are indeed full members of the academic community.

There was not as much unanimity on the part of the committee members as to what was ideal and possible as we might have liked. Compromising, which we would rather and which we had better, was not easy. In this respect, if in no other, the members demonstrated their essentially academic nature-each of us knew best what was required and what should be recommended. Some of the major issues we grappled with were whether professorial titles should be used or not, the degree to which participatory democracy was desirable or possible in traditionally hierarchical academic libraries, and the degree to which librarians should be free to use their time as they see fit. I think no arguments relating to these basic points, or any others for that matter, were overlooked.

The recommended standards were reported to the ACRL Board at the Detroit ALA Conference and were approved in principle by the Board subject to further comments from the membership. It might be noted that the ACRL is working with other educational associations, in hopes that the final ACRL status recommendation will have their endorsement.

At the present time, the committee hopes that opinions from the profession on the proposed standards will be forthcoming (no pun intended) for our future guidance.

Committee members are:

Chairman: Stuart Forth, Director of Libraries, University of Kentucky; Ben C. Bowman, University of Rochester, Rhees Library; Rev. Brendan Connolly, Director of Libraries, Boston College; Anthony Greco, Jr., University of California, Los Angeles; Beverly Johnson, Serials Librarian, San Diego State College Library; E. J. Josey, Academic and Research Libraries Consultant, Academic and Research Library, New York State Library; Arthur M. McAnally, Director, University of Oklahoma Libraries; Rev. Vincent R. Negherbon, President, Saint Francis College, Loretto, Pennsylvania; and Eldred Smith, Head, Search Division, University Library, University of California, Berkeley.

\section{PROPOSED STANDARDS}

With publication increasing at an exponential rate, with the variety of forms of publication proliferating rapidly, with significant scholarly and informational material appearing in all of the world's languages, with the bibliographical apparatus of many fields and subfields becoming increasingly difficult to use, with the grnw-

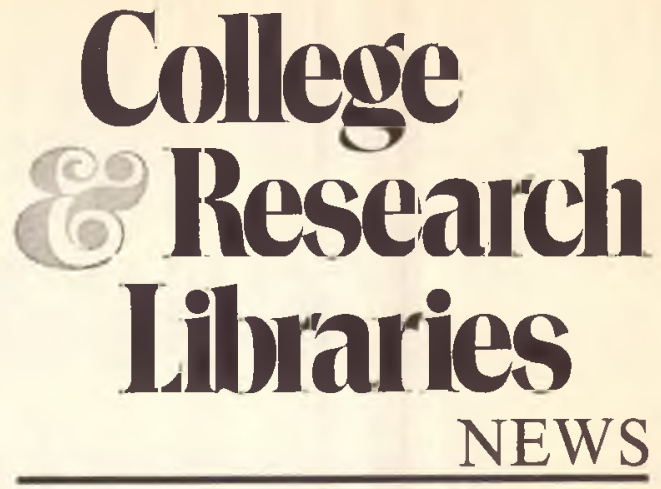

News Editor, Michael Herbison, Casper College, Casper, Wyoming 82601.

Editor, Richard M. Dougherty, School of Library Science, Syracuse University, Syracuse, New York 13210.

Editorial Board: William Axford, Arizona State University; Richard De Gennaro, University of Pennsylvania; Fred J. HernRITz, Southern Connecticut State College; David HERoN, University of Kansas; Peter Hiat, Western Interstate Commission for Higher Education, Boulder, Colorado; Elısworth G. Mason, Hofstra University.

ACRL Officers, 1970/71: President, Anne C. Edmonds; Chairman, College Libraries Section, Carl H. Sachtleben; Junior College Libraries Section, Mrs. Joleen Bock; Rare Books Section, Julius P. Barclay; Subject Specialists Section, Eleanor Buist; Agricultural and Biological Sciences Subsection, Joseph C. Shipman; Art Subsection, Peter Anthony; Asian and North African Subsection, Joyce Wright; Education and Behavioral Sciences Subsection, Dr. Sidney Forman; Law and Political Science Subsection, Dr. Otto G. Gara; Slavic and East European Subsection, Dr. Ivan L. Kaldor; University Libraries Section, David W. Heron.

News from the Field, Personnel profiles and notes, classified advertising, official matter of ACRL, and other material of a timely nature is published in the News issues of College \& Research Libraries.

Inclusion of an article or advertisement in $C R L$ does not constitute official endorsement by ACRL or ALA. Production and Advertising and Circulation office: 50 E. Huron St., Chicago, Ill. 60611. Change of address and orders for subscriptions should be addressed to College of Research Libraries, for receipt at the above address, at least two months before the publication date of the effective issue.

Subscription to $C R L$ is included in membership dues to $A C R L$ of $\$ 6$ or more; other subscriptions to $C R L$ are $\$ 10$ per year. Neither subscriptions nor memberships include miscellaneous unscheduled supplements, which are available by purchase only, Retroactive subscriptions are not accepted. Single journal copies are available at $\$ 1.50$ each and News issues at $\$ 1.00$ each from ALA Publishing Department.

Indexed in Current Contents, Library Literature, and Science Citation Index. Abstracted in Library Science Abstracts. Book reviews indexed in Book Review Index. College \& Research Libraties is the official journal of the Association of College and Research Libraries, a division of the American Library Association; and is published seventeen times per year-bi-monthly as a technical journal with 11 monthly News issues, combining July-August-at 1201-05 Bluff St., Fulton, Mo 65251 .

Second-class postage paid at Fulton, Mo. 
ing sophistication of library and information technology, and with the development of academic libraries into large and complex organizations, the work of the academic librarian has become highly specialized and demanding.

Consequently, the academic librarian makes a unique and important contribution to American higher education. He bears central responsibility for developing college and university library collections, for extending bibliographical control over these collections, and for instructing students (both formally in the classroom and informally in the library), and advising faculty and scholars in the use of these collections. He provides a variety of information services to the college or university community, ranging from answers to specific questions to the compilation of extensive bibliographies. He provides library and information services to the community at large, including federal, state, and local government agencies, business firms and other organizations, and private citizens. Through his own research into the information process and through bibliographical and other studies, he adds to the sum of knowledge in the field of library practice and information science. Through membership and participation in library and scholarly organizations, he works to improve the practice of academic librarianship, bibliography, and information service.

\section{Standards for Faculty Status} Fon COllege and UNIVERSITy Librarians

\section{A Proposal of the Academic Status Committee \\ Association of College and Research Libraries}

Without the librarian, the quality of teaching, research and public service in our colleges and universities would deteriorate seriously, and programs in many disciplines could no longer be performed. His contribution is intellectual in nature and is the product of considerable formal education, including professional training at the graduate level. Therefore, college and university librarians must be recognized as equal partners in the academic enterprise, and they must be extended the rights and privileges which are not only commensurate with their contributions, but are necessary if they are to carry out their responsibilities.

The Committee on Academic Status of the Association of College and Research Libraries strongly endorses the formal recognition of the college or university librarian's academic status by all institutions of higher education and their governing bodies. It urges that the Association of College and Research Libraries and the American Library Association adopt as standards the following rights and privileges for all academic librarians:
1. Self-determination on the job. Each librarian should be assigned general responsibilities within his particular area of competence, and his work should be judged on the basis of how he fulfills this assignment. A review of his performance by a committee of peers, who have access to all available evidence, is a necessary element of any evaluation of his work.

2. Compensation. The salary scale for librarians should be the same as that for other academic categories with equivalent education and experience. In this respect, two master's degrees-in librarianship and in a relevant subject field-together with a minimum of two years experience as a librarian should be equated with a doctorate. Librarians should normally be appointed for the academic year. If a librarian is expected to work through the summer session, his salary scale should be adjusted similarly to the summer session scale of faculty at his college or university.

3. Tenure. Librarians should be covered by tenure provisions the same as those of faculty. In the pre-tenure period, librarians should be covered by written contracts or agreements the same as those of faculty.

4. Promotion. Librarians should be promoted through ranks and steps on the basis of their academic proficiency and professional effectiveness. A peer review system similar to that used by the faculty is the basis of judgment in the promotion process for academic librarians. The librarians' promotion ladder should have the same titles, ranks, and steps as that of the faculty.

5. Leaves. Sabbatical and other research leaves should be available to librarians on the same basis, and with the same requirements, as they are available to faculty.

6. Research funds. Librarians should have access to funding for research projects on the same basis as faculty and other academic categories.

7. Library governance. College and university libraries should adopt an academic form of governance. The librarians should form a library faculty, whose role and authority is similar to that of the faculties of the departments, schools, or colleges.

8. College and university governance. Librarians should be eligible for membership in the academic senate or equivalent body at their college or university on the same basis as the faculty.

9. Academic freedom. Librarians in colleges and universities must have the protection of academic freedom. Library resources 
and the professional judgment of librarians must not be subject to censorship."

To implement these standards, the Association of College and Research Libraries and the American Library Association will:

1. Publicize these standards to all colleges and universities and their libraries, all library schools, all library organizations, all higher education organizations, and all agencies which accredit academic institutions.

2. Seek to have these standards formally adopted or endorsed by all colleges and universities and their libraries, all library schools, all library organizations, all higher education organizations, and all agencies which accredit academic institutions.

3. Investigate all violations of these standards which are reported by members of the Association of College and Research Libraries. Such investigations will be coordinated and supervised by the Academ-

* Wherever equivalence is mentioned in this document, it refers to an equivalence between librarians and faculty at the same college or university. ic Status Committee of the Association of College and Research Libraries.

4. Invoke the following sanctions against institutions of higher education which are found, after such investigation, to be in violation of any or all of these standards:

a. Publicize the violation and the institution concerned in College \& Research Libraries News and other appropriate publications.

b. Refuse to accept advertisements in any ALA publication for positions at that institution.

c. Discourage its members from accepting employment at that institution, through notices in its publications and other means.

A reasonable amount of time-three to five years-should be provided college and university libraries which do not currently conform to any or all of these standards to enable them to do so. However, no such grace period should be provided to librarians which currently do conform, either wholly or in part, and which seek to deny or withdraw any such rights and privileges.

\section{From Inside the DLP}

\section{By Dr. Katharine M. Stokes}

College and University Library Specialist, Training and Resources Branch, Division of Library Programs, Bureau of Libraries and Educational Technology, U.S. Office of Education, Washington, D.C. 20202.

On June 25, 1970, the members of Congress were notified by the Office of Education that 279 basic and supplemental grants had been made to 169 applicants for the purchase of library materials under Title II-A (HEA). On April 30, 2,032 applicants had been approved for awards, but it must have been a pleasant surprise to the institutions on the second list to

\section{IS THERE AN}

MPE

IN YOUR

BUDGET?

See Page 286 learn that their applications had also been successful. The delay in their approval occurred because their replies to inquiries from the Accreditation and Eligibility Staff of the Bureau of Higher Education had not been received in time for the April list. It was thought best to notify the large group and hold back funds to cover the grants for which some 200 institutions might later qualify.

When the determination of eligibility was completed, not all of the funds retained were needed to fund the approved institutions at the level of those on the April list. The extra money was divided among the thirty-five junior colleges and colleges serving only undergraduates which had rated highest in deficiency of size of collection. Since the Higher Education Act of 1965 allows no more than $\$ 10$ to be awarded for colleges' library resources for each full-time equivalent student enrolled in an institution, the amount already awarded to each of the thirty-five libraries per FTE student was subtracted from $\$ 10$ and the difference multiplied by its FTE figure. The resulting sum was added to the supplemental award about which the individual institutions had been notified in May. Although the amounts were rather insignificant for colleges with small enrollments, for a few junior colleges with large enrollments they could mean a substantial improvement in the size of the library collection available to their students. 